\title{
Ferrocene Derivatives Carrying Urea, Thiourea, and Sulfonamide Moieties: Synthesis and Evaluation of Antibacterial and Antifungal Activities
}

\author{
Serkan Yavuz ${ }^{1}$ and Hilal Yıldırım ${ }^{2}$ \\ ${ }^{1}$ Department of Chemistry, Faculty of Science, Gazi University, 06500 Ankara, Turkey \\ ${ }^{2}$ Department of Chemistry, Faculty of Science and Arts, Kırıkkale University, 71450 Kırıkkale, Turkey
}

Correspondence should be addressed to Serkan Yavuz; syavuz@gazi.edu.tr

Received 26 May 2013; Accepted 1 July 2013

Academic Editor: Fernanda Carvalho

Copyright (C) 2013 S. Yavuz and H. Ylldırım. This is an open access article distributed under the Creative Commons Attribution License, which permits unrestricted use, distribution, and reproduction in any medium, provided the original work is properly cited.

In the present study, some novel ferrocene derivatives carrying urea, thiourea, and sulfonamide groups were synthesized, and all compounds were characterized by spectral and elemental analyses. These compounds were screened for their antibacterial activities and also their minimum inhibitory concentration (MIC) against Gram-positive bacteria (Staphylococcus aureus and Bacillus subtilis) and Gram-negative bacteria (Klebsiella pneumonia and Escherichia coli) and antifungal activities against Saccharomyces cerevisiae and Candida albicans. Amongst the tested compounds, $\mathbf{4 b}, \mathbf{4 c}, \mathbf{5 b}$, and $\mathbf{6 b}$ displayed excellent antimicrobial activity.

\section{Introduction}

Although there are many important developments in antimicrobial therapy infectious diseases caused by bacteria and fungi remain a major global health problem because of the rapid development of resistance to the existing antimicrobial drugs, in other words, the increasing use and misuse of the existing antimicrobial drugs have resulted in the development of resistant pathogens [1-3]. Therefore, novel antimicrobial agents are needed for effective treatment against infections caused by the pathogenic microbes.

Ferrocene and its derivatives find extensive applications in areas like homogeneous catalysis, material science, nonlinear optics, and molecular sensors [4-10]. Additionally, incorporation of a ferrocene fragment into a molecule of an organic compound often produces unexpected biological activity. Recently, some new ferrocenyl-substituted organic compounds as potential pharmaceuticals have been reported [11-15]. Many ferrocenyl compounds display interesting cytotoxic, antitumor, antimalarial, antifungal, antioxidant, and DNA-cleaving activity [16-18].

In addition, some urea, thiourea, and sulfonamide derivatives are known to be associated with a wide range of biological activities such as analgesic, antitumor, antioxidant, anticonvulsant, and anti-HIV properties [19-28]. However, antibacterial and antifungal activities of urea and thiourea derivatives have been less widely documented $[29,30]$. In view of the above-mentioned facts and in an attempt to achieve potential antibacterial and antifungal agents, in the present study we hereby report the synthesis of some ferrocenyl substituted urea, thiourea, and sulfonamide derivatives and evaluation of their in vitro antimicrobial activities. The structural characterization and preliminary biological evaluation of these novel compounds could be interesting for screening potent drug.

\section{Experimental}

All the reagents for syntheses were commercially available and used without further purification or purified by standard methods prior to use. Melting points were determined using an Electrothermal 9100 apparatus, uncorrected. All NMR spectra were recorded on a Bruker $400\left({ }^{1} \mathrm{H}: 400 \mathrm{MHz},{ }^{13} \mathrm{C}\right.$ : $100 \mathrm{MHz}$ ) NMR spectrometer, in $\mathrm{CDCl}_{3}$. Chemical shift values were reported in $\mathrm{ppm}$ relative to those for TMS used as an internal reference standard, $J$ in $\mathrm{Hz}$. The elemental analyses for $\mathrm{C}, \mathrm{H}, \mathrm{N}$, and $\mathrm{S}$ were done on LECO, CHNS-932. FTIR spectra were recorded on a Mattson 1000 spectrometer 
using $\mathrm{KBr}$ pellets. The progress of reactions was monitored by TLC using Silufol UV-254 plates. The compounds 2 and 3 were synthesized using a published method. All the physical and spectral data were in line with the previously reported results $[31,32]$.

2.1. General Procedure for Synthesis of $(\mathbf{4 a - 4 e )}$. A stirred mixture of 4-ferrocenylaniline $(3,2.77 \mathrm{~g}, 10 \mathrm{mmol})$ and a molequivalent amount of the corresponding phenyl isocyanate in $20 \mathrm{~mL}$ ethanol is heated under reflux for $2 \mathrm{~h}$ (TLC control). At the end of this period, the reaction mixture was evaporated to dryness. This crude product was recrystallized from an appropriate solvent to afford the desired compound.

2.1.1. 1-(4-Ferrocenylphenyl)-3-phenylurea (4a). Crystallization from ethanol; orange powder, $83 \%$ yield; $\mathrm{mp} 181-182^{\circ} \mathrm{C}$; IR $\left(\nu, \mathrm{cm}^{-1}\right): 3054,1639,1611 .{ }^{1} \mathrm{H}-\mathrm{NMR}\left(400 \mathrm{MHz}, \mathrm{CDCl}_{3}\right)$ : $10.85(1 \mathrm{H}, \mathrm{s}, \mathrm{NH}), 9.51(1 \mathrm{H}, \mathrm{s}, \mathrm{NH}), 7.82(2 \mathrm{H}, \mathrm{d}, J=8.6 \mathrm{~Hz}, \mathrm{Ar}-$ $\mathrm{H}), 7.56(2 \mathrm{H}, \mathrm{d}, J=8.6 \mathrm{~Hz}, \mathrm{Ar}-\mathrm{H}), 6.97-7.48(5 \mathrm{H}, \mathrm{m}, \mathrm{Ar}-\mathrm{H})$, $5.01\left(2 \mathrm{H}, \mathrm{s}, \mathrm{C}_{5} \mathrm{H}_{4}\right), 4.48\left(2 \mathrm{H}, \mathrm{s}, \mathrm{C}_{5} \mathrm{H}_{4}\right), 4.02\left(5 \mathrm{H}, \mathrm{s}, \mathrm{C}_{5} \mathrm{H}_{5}\right) .{ }^{13} \mathrm{C}-$ NMR (100 MHz, $\mathrm{CDCl}_{3}$ ): 64.3, 68.7, 69.4, 86.1, 121.3, 122.0, $128.3,129.1,131.6,133.9,138.4,140.2$, 156.4. Elemental analysis for $\mathrm{C}_{23} \mathrm{H}_{20} \mathrm{FeN}_{2} \mathrm{O}$ : Calculated: C, 69.71; H, 5.09; N, 7.07\%. Found: C, 69.81; H, 5.01; N, 7.19\%.

2.1.2. 1-(4-Chlorophenyl)-3-(4-ferrocenylphenyl)urea (4b). Crystallization from ethanol; yellow powder, $87 \%$ yield; $\mathrm{mp} 166-167^{\circ} \mathrm{C}$; IR $\left(\nu, \mathrm{cm}^{-1}\right): 3067,1632,1604 .{ }^{1} \mathrm{H}-\mathrm{NMR}$ $\left(400 \mathrm{MHz}_{\mathrm{CDCl}}\right)$ ): $10.93(\mathrm{H}, \mathrm{s}, \mathrm{NH}), 9.43(1 \mathrm{H}, \mathrm{s}, \mathrm{NH}), 7.73$ $(2 \mathrm{H}, \mathrm{d}, J=8.4 \mathrm{~Hz}, \mathrm{Ar}-\mathrm{H}), 7.59(2 \mathrm{H}, \mathrm{d}, J=8.0 \mathrm{~Hz}, \mathrm{Ar}-\mathrm{H}), 7.56$ $(2 \mathrm{H}, \mathrm{d}, J=8.4 \mathrm{~Hz}, \mathrm{Ar}-\mathrm{H}), 7.45(2 \mathrm{H}, \mathrm{d}, J=8.0 \mathrm{~Hz}, \mathrm{Ar}-\mathrm{H})$, $4.93\left(2 \mathrm{H}, \mathrm{s}, \mathrm{C}_{5} \mathrm{H}_{4}\right), 4.45\left(2 \mathrm{H}, \mathrm{s}, \mathrm{C}_{5} \mathrm{H}_{4}\right), 4.01\left(5 \mathrm{H}, \mathrm{s}, \mathrm{C}_{5} \mathrm{H}_{5}\right)$. ${ }^{13} \mathrm{C}-\mathrm{NMR}\left(100 \mathrm{MHz}, \mathrm{CDCl}_{3}\right): 65.9,69.3,70.7,87.2,115.9$, 122.5, 127.1, 129.0, 135.5, 139.2, 139.9, 141.1, 156.1. Elemental analysis for $\mathrm{C}_{23} \mathrm{H}_{19} \mathrm{ClFeN}_{2} \mathrm{O}$ : Calculated: C, 64.14; $\mathrm{H}, 4.45$; N, 6.50\%. Found: C, 64.04; H, 4.41; N, 6.45\%.

2.1.3. 1-(4-Bromophenyl)-3-(4-ferrocenylphenyl)urea (4c). Crystallization from butanol; yellow powder, $80 \%$ yield; $\mathrm{mp} 201-202^{\circ} \mathrm{C}$; IR $\left(\nu, \mathrm{cm}^{-1}\right): 3084,1629,1601 .{ }^{1} \mathrm{H}-\mathrm{NMR}$ $\left(400 \mathrm{MHz}_{\mathrm{CDCl}}\right)$ ): $10.73(1 \mathrm{H}, \mathrm{s}, \mathrm{NH}), 9.62(1 \mathrm{H}, \mathrm{s}, \mathrm{NH}), 7.92$ $(2 \mathrm{H}, \mathrm{d}, J=8.3 \mathrm{~Hz}, \mathrm{Ar}-\mathrm{H}), 7.61(2 \mathrm{H}, \mathrm{d}, J=8.3 \mathrm{~Hz}, \mathrm{Ar}-\mathrm{H}), 7.54$ $(2 \mathrm{H}, \mathrm{d}, J=8.6 \mathrm{~Hz}, \mathrm{Ar}-\mathrm{H}), 7.46(2 \mathrm{H}, \mathrm{d}, J=8.6 \mathrm{~Hz}, \mathrm{Ar}-\mathrm{H})$, $4.96\left(2 \mathrm{H}, \mathrm{s}, \mathrm{C}_{5} \mathrm{H}_{4}\right), 4.44\left(2 \mathrm{H}, \mathrm{s}, \mathrm{C}_{5} \mathrm{H}_{4}\right), 4.02\left(5 \mathrm{H}, \mathrm{s}, \mathrm{C}_{5} \mathrm{H}_{5}\right)$. ${ }^{13} \mathrm{C}-\mathrm{NMR}\left(100 \mathrm{MHz} \mathrm{CDCl}_{3}\right): 64.3,69.0,69.5,86.3,118.4$, 121.6, 122.1, 124.9, 135.3, 139.0, 139.4, 141.3, 155.0. Elemental analysis for $\mathrm{C}_{23} \mathrm{H}_{19} \mathrm{BrFeN}_{2} \mathrm{O}$ : Calculated: C, 58.14; $\mathrm{H}, 4.03$; N, 5.90\%. Found: C, 58.04; H, 4.00; N, 6.02\%.

2.1.4. 1-(4-Ferrocenylphenyl)-3-p-tolylurea (4d). Crystallization from ethanol; orange powder, $74 \%$ yield; mp $146-147^{\circ} \mathrm{C}$; IR $\left(\nu, \mathrm{cm}^{-1}\right): 3053,2987,1632,1609 .{ }^{1} \mathrm{H}-\mathrm{NMR}(400 \mathrm{MHz}$, $\left.\mathrm{CDCl}_{3}\right): 10.84(1 \mathrm{H}, \mathrm{s}, \mathrm{NH}), 9.49(1 \mathrm{H}, \mathrm{s}, \mathrm{NH}), 7.80(2 \mathrm{H}, \mathrm{d}, J$ $=8.5 \mathrm{~Hz}, \mathrm{Ar}-\mathrm{H}), 7.55(2 \mathrm{H}, \mathrm{d}, J=8.5 \mathrm{~Hz}, \mathrm{Ar}-\mathrm{H}), 7.30(2 \mathrm{H}, \mathrm{d}$, $J=8.2 \mathrm{~Hz}, \mathrm{Ar}-\mathrm{H}), 7.11(2 \mathrm{H}, \mathrm{d}, J=8.2 \mathrm{~Hz}, \mathrm{Ar}-\mathrm{H}), 4.94(2 \mathrm{H}$, $\left.\mathrm{s}, \mathrm{C}_{5} \mathrm{H}_{4}\right), 4.45\left(2 \mathrm{H}, \mathrm{s}, \mathrm{C}_{5} \mathrm{H}_{4}\right), 4.01\left(5 \mathrm{H}, \mathrm{s}, \mathrm{C}_{5} \mathrm{H}_{5}\right), 2.32(3 \mathrm{H}$, s, $\left.\mathrm{CH}_{3}\right) .{ }^{13} \mathrm{C}-\mathrm{NMR}\left(100 \mathrm{MHz}, \mathrm{CDCl}_{3}\right): 22.2,64.1,68.8,69.3$,
86.0, 118.1, 119.3, 124.8, 127.6, 133.2, 136.9, 138.8, 141.2, 155.8. Elemental analysis for $\mathrm{C}_{24} \mathrm{H}_{22} \mathrm{FeN}_{2} \mathrm{O}$ : Calculated: $\mathrm{C}, 70.26 ; \mathrm{H}$, $5.40 ; \mathrm{N}, 6.83 \%$. Found: C, 70.34; H, 5.46; N, 6.75\%.

2.1.5. 1-(4-Ferrocenylphenyl)-3-(4-methoxyphenyl)urea (4e). Crystallization from ethanol; orange powder, $86 \%$ yield; $\mathrm{mp}$ 173-174 ${ }^{\circ} \mathrm{C}$; IR $\left(\nu, \mathrm{cm}^{-1}\right): 3078,2993,1639,1612 .{ }^{1} \mathrm{H}-\mathrm{NMR}$ $\left(400 \mathrm{MHz}_{\mathrm{CDCl}}\right): 10.91(1 \mathrm{H}, \mathrm{s}, \mathrm{NH}), 9.43(1 \mathrm{H}, \mathrm{s}, \mathrm{NH}), 7.84$ $(2 \mathrm{H}, \mathrm{d}, J=8.4 \mathrm{~Hz}, \mathrm{Ar}-\mathrm{H}), 7.60(2 \mathrm{H}, \mathrm{d}, J=8.4 \mathrm{~Hz}, \mathrm{Ar}-\mathrm{H})$, $7.50(2 \mathrm{H}, \mathrm{d}, J=8.9 \mathrm{~Hz}, \mathrm{Ar}-\mathrm{H}), 9.93(2 \mathrm{H}, \mathrm{d}, J=8.9 \mathrm{~Hz}, \mathrm{Ar}-\mathrm{H})$, $4.96\left(2 \mathrm{H}, \mathrm{s}, \mathrm{C}_{5} \mathrm{H}_{4}\right), 4.43\left(2 \mathrm{H}, \mathrm{s}, \mathrm{C}_{5} \mathrm{H}_{4}\right), 4.02\left(5 \mathrm{H}, \mathrm{s}, \mathrm{C}_{5} \mathrm{H}_{5}\right)$, $3.32\left(3 \mathrm{H}, \mathrm{s}, \mathrm{OCH}_{3}\right) .{ }^{13} \mathrm{C}-\mathrm{NMR}\left(100 \mathrm{MHz} \mathrm{CDCl}_{3}\right): 55.2,64.4$, 69.0, 69.6, 86.1, 113.2, 118.3, 119.9, 124.6, 130.0, 138.8, 141.1, 154.2, 155.9. Elemental analysis for $\mathrm{C}_{24} \mathrm{H}_{22} \mathrm{FeN}_{2} \mathrm{O}_{2}$ : Calculated: $\mathrm{C}$, $67.62 ; \mathrm{H}, 5.20 ; \mathrm{N}, 6.57 \%$. Found: C, 67.55; H, 5.12; N, 6.49\%.

2.2. General Procedure for Synthesis of (5a-5e). A stirred mixture of 4 -ferrocenylaniline $(2.77 \mathrm{~g}, 10 \mathrm{mmol})$ and a molequivalent amount of the corresponding phenyl isocyanate in $20 \mathrm{~mL}$ ethanol is heated under reflux for $2 \mathrm{~h}$ (TLC control). At the end of this period, the reaction mixture was evaporated to dryness. This crude product was recrystallized from an appropriate solvent to afford the desired compound.

2.2.1. 1-(4-Ferrocenylphenyl)-3-phenylthiourea (5a). Crystallization from methanol; brown powder, 79\% yield; mp 167-

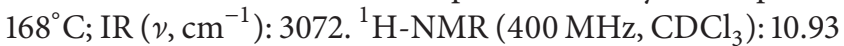
(1H, s, NH), $9.82(1 \mathrm{H}, \mathrm{s}, \mathrm{NH}), 7.20-7.73(7 \mathrm{H}, \mathrm{m}, \mathrm{Ar}-\mathrm{H}), 6.80$ $(2 \mathrm{H}, \mathrm{d}, J=8.6 \mathrm{~Hz}, \mathrm{Ar}-\mathrm{H}), 5.02\left(2 \mathrm{H}, \mathrm{s}, \mathrm{C}_{5} \mathrm{H}_{4}\right), 4.47(2 \mathrm{H}$, $\left.\mathrm{s}, \mathrm{C}_{5} \mathrm{H}_{4}\right), 4.00\left(5 \mathrm{H}, \mathrm{s}, \mathrm{C}_{5} \mathrm{H}_{5}\right) .{ }^{13} \mathrm{C}-\mathrm{NMR}\left(100 \mathrm{MHz}, \mathrm{CDCl}_{3}\right)$ : 63.7, 68.7, 69.3, 85.5, 119.7, 122.6, 124.3, 127.7, 130.3, 138.1, 138.4, 143.2, 180.2. Elemental analysis for $\mathrm{C}_{23} \mathrm{H}_{20} \mathrm{FeN}_{2} \mathrm{~S}$ : Calculated: C, 67.00; H, 4.89; N, 6.79; S, 7.78\%. Found: C, 66.91; H, 4.84; $\mathrm{N}, 6.73 ; \mathrm{S} 7.64 \%$.

2.2.2. 1-(4-Chlorophenyl)-3-(4-ferrocenylphenyl)thiourea (5b). Crystallization from butanol; yellow powder, $81 \%$ yield; $\mathrm{mp}$ 157-158 ${ }^{\circ} \mathrm{C}$; IR $\left(\nu, \mathrm{cm}^{-1}\right): 3081 .{ }^{1} \mathrm{H}-\mathrm{NMR}\left(400 \mathrm{MHz}, \mathrm{CDCl}_{3}\right)$ : $11.01(1 \mathrm{H}, \mathrm{s}, \mathrm{NH}), 9.85(1 \mathrm{H}, \mathrm{s}, \mathrm{NH}), 7.67(2 \mathrm{H}, \mathrm{d}, J=8.5 \mathrm{~Hz}$, Ar-H), $7.16(2 \mathrm{H}, \mathrm{d}, J=8.2 \mathrm{~Hz}, \mathrm{Ar}-\mathrm{H}), 6.93(2 \mathrm{H}, \mathrm{d}, J=$ $8.5 \mathrm{~Hz}, \mathrm{Ar}-\mathrm{H}), 6.69(2 \mathrm{H}, \mathrm{d}, J=8.2 \mathrm{~Hz}, \mathrm{Ar}-\mathrm{H}), 5.03(2 \mathrm{H}, \mathrm{s}$, $\left.\mathrm{C}_{5} \mathrm{H}_{4}\right), 4.49\left(2 \mathrm{H}, \mathrm{s}, \mathrm{C}_{5} \mathrm{H}_{4}\right), 4.04\left(5 \mathrm{H}, \mathrm{s}, \mathrm{C}_{5} \mathrm{H}_{5}\right) .{ }^{13} \mathrm{C}-\mathrm{NMR}$ $\left(100 \mathrm{MHz}, \mathrm{CDCl}_{3}\right): 63.9,68.6,69.4,85.9,119.5,122.5,124.3$, $127.7,130.3,138.1,138.3,143.2,179.2$. Elemental analysis for $\mathrm{C}_{23} \mathrm{H}_{19} \mathrm{ClFeN}_{2} \mathrm{~S}$ : Calculated: C, 61.83; H, 4.29; N, 6.27; S, 7.18\%. Found: C, 61.96; H, 4.25; N, 6.24; S, 7.10\%.

2.2.3. 1-(4-Bromophenyl)-3-(4-ferrocenylphenyl)thiourea (5c). Crystallization from ethanol; orange powder, $89 \%$ yield; $\mathrm{mp}$ 189-190 ${ }^{\circ} \mathrm{C}$; IR $\left(\nu, \mathrm{cm}^{-1}\right): 3046 .{ }^{1} \mathrm{H}-\mathrm{NMR}\left(400 \mathrm{MHz}, \mathrm{CDCl}_{3}\right)$ : 11.03 (s, 1H, NH), 9.94 (s, $1 \mathrm{H}, \mathrm{NH}), 7.70(2 \mathrm{H}, \mathrm{d}, J=8.5 \mathrm{~Hz}$, Ar-H), $7.42(2 \mathrm{H}, \mathrm{d}, J=8.8 \mathrm{~Hz}, \mathrm{Ar}-\mathrm{H}), 6.92(2 \mathrm{H}, \mathrm{d}, J=$ $8.5 \mathrm{~Hz}, \mathrm{Ar}-\mathrm{H}), 6.73(2 \mathrm{H}, \mathrm{d}, J=8.8 \mathrm{~Hz}, \mathrm{Ar}-\mathrm{H}), 5.03(2 \mathrm{H}, \mathrm{s}$, $\left.\mathrm{C}_{5} \mathrm{H}_{4}\right), 4.47\left(2 \mathrm{H}, \mathrm{s}, \mathrm{C}_{5} \mathrm{H}_{4}\right), 4.01\left(5 \mathrm{H}, \mathrm{s}, \mathrm{C}_{5} \mathrm{H}_{5}\right) .{ }^{13} \mathrm{C}-\mathrm{NMR}$ $\left(100 \mathrm{MHz}, \mathrm{CDCl}_{3}\right): 64.2,68.9,69.7,86.3,117.3,122.1,125.2$, $132.8,133.5,137.2,139.4,140.3,179.3$. Elemental analysis for 
$\mathrm{C}_{23} \mathrm{H}_{19} \mathrm{BrFeN}_{2} \mathrm{~S}$ : Calculated: C, 56.24; H, 3.90; N, 5.70; S, $6.53 \%$. Found: C, 56.14; H, 3.83; N, 5.63; S, 6.45\%.

2.2.4. 1-(4-Ferrocenylphenyl)-3-p-tolylthiourea (5d). Crystallization from ethanol; brown powder, $80 \%$ yield; $\mathrm{mp} 111-112^{\circ} \mathrm{C}$; $\operatorname{IR}\left(\nu, \mathrm{cm}^{-1}\right): 3061 .{ }^{1} \mathrm{H}-\mathrm{NMR}\left(400 \mathrm{MHz}, \mathrm{CDCl}_{3}\right): 10.95(1 \mathrm{H}, \mathrm{s}$, $\mathrm{NH}), 9.86(1 \mathrm{H}, \mathrm{s}, \mathrm{NH}), 7.65(2 \mathrm{H}, \mathrm{d}, J=8.6 \mathrm{~Hz}, \mathrm{Ar}-\mathrm{H}), 7.02$ $(2 \mathrm{H}, \mathrm{d}, J=8.3 \mathrm{~Hz}, \mathrm{Ar}-\mathrm{H}), 6.88(2 \mathrm{H}, \mathrm{d}, J=8.6 \mathrm{~Hz}, \mathrm{Ar}-\mathrm{H})$, $6.79(2 \mathrm{H}, \mathrm{d}, J=8.3 \mathrm{~Hz}, \mathrm{Ar}-\mathrm{H}), 5.04\left(2 \mathrm{H}, \mathrm{s}, \mathrm{C}_{5} \mathrm{H}_{4}\right), 4.45(2 \mathrm{H}$, $\left.\mathrm{s}, \mathrm{C}_{5} \mathrm{H}_{4}\right), 4.02\left(5 \mathrm{H}, \mathrm{s}, \mathrm{C}_{5} \mathrm{H}_{5}\right), 2.27\left(3 \mathrm{H}, \mathrm{s}, \mathrm{CH}_{3}\right) .{ }^{13} \mathrm{C}-\mathrm{NMR}$ $\left(100 \mathrm{MHz} \mathrm{CDCl}_{3}\right): 21.5,63.9,68.6,69.6,85.8,117.8,123.7,127.2$, $133.4,135.1,138.8,139.6,142.5,180.5$. Elemental analysis for $\mathrm{C}_{24} \mathrm{H}_{22} \mathrm{FeN}_{2} \mathrm{~S}$ : Calculated: C, 67.61; H, 5.20; N, 6.57; S, 7.52\%. Found: C, 67.46; H, 5.14; N, 6.49; S, 7.41\%.

2.2.5. 1-(4-Ferrocenylphenyl)-3-(4-methoxyphenyl)thiourea (5e). Crystallization from butanol; brown powder, $83 \%$ yield; mp 182-183 ${ }^{\circ} \mathrm{C}$; IR $\left(\nu, \mathrm{cm}^{-1}\right): 3059 .{ }^{1} \mathrm{H}-\mathrm{NMR}(400 \mathrm{MHz}$, $\left.\mathrm{CDCl}_{3}\right): 10.92(1 \mathrm{H}, \mathrm{s}, \mathrm{NH}), 9.83(1 \mathrm{H}, \mathrm{s}, \mathrm{NH}), 7.72(2 \mathrm{H}, \mathrm{d}, J=$ $8.4 \mathrm{~Hz}, \mathrm{Ar}-\mathrm{H}), 6.89(2 \mathrm{H}, \mathrm{d}, J=8.4 \mathrm{~Hz}, \mathrm{Ar}-\mathrm{H}), 6.83(2 \mathrm{H}, \mathrm{d}$, $J=8.8 \mathrm{~Hz}, \mathrm{Ar}-\mathrm{H}), 6.77(2 \mathrm{H}, \mathrm{d}, J=8.8 \mathrm{~Hz}, \mathrm{Ar}-\mathrm{H}), 5.02(2 \mathrm{H}$, $\left.\mathrm{s}, \mathrm{C}_{5} \mathrm{H}_{4}\right), 4.43\left(2 \mathrm{H}, \mathrm{s}, \mathrm{C}_{5} \mathrm{H}_{4}\right), 4.01\left(5 \mathrm{H}, \mathrm{s}, \mathrm{C}_{5} \mathrm{H}_{5}\right), 3.21(3 \mathrm{H}, \mathrm{s}$, $\left.\mathrm{OCH}_{3}\right) .{ }^{13} \mathrm{C}-\mathrm{NMR}\left(100 \mathrm{MHz}, \mathrm{CDCl}_{3}\right): 53.2,64.2,68.8,69.7$, 85.9, 114.6, 118.2, 122.2, 125.3, 132.1, 139.3, 141.5, 155.3, 179.7 . Elemental analysis for $\mathrm{C}_{24} \mathrm{H}_{22} \mathrm{FeN}_{2} \mathrm{OS}$ : Calculated: C, 65.16; H, 5.01; N, 6.33; S, 7.25\%. Found: C, 65.10; H, 5.03; N, 6.26; S, $7.33 \%$.

2.3. General Procedure for Synthesis of $(\mathbf{6} \boldsymbol{a}-\mathbf{6} \boldsymbol{d})$. A mixture of 4-ferrocenylaniline $(2.77 \mathrm{~g}, 10 \mathrm{mmol})$, dicyclohexylcarbodiimide (2.06 g, $10 \mathrm{mmol} \mathrm{DCC})$, and $4-N, N^{\prime}$-dimethylaminopyridine $(1.22 \mathrm{~g}, 10 \mathrm{mmol}$ DMAP) in dichloromethane was stirred at $0^{\circ} \mathrm{C}$ for $3 \mathrm{~h}$. Then the corresponding sulfonic acid derivatives were added to the mixture. After $2 \mathrm{~h}$, the temperature of the solution was allowed to increase to room temperature, and the solution was stirred at this temperature for $12 \mathrm{~h}$. The precipitated $N, N^{\prime}$-dicyclohexylurea was removed by filtration, with the filtrate being extracted with $10 \% \mathrm{NaHCO}_{3}$. The organic phase evaporated, and the precipitate that occurred was filtrated and crystallized from an appropriate solvent to afford the desired compound.

2.3.1. N-(4-Ferrocenylphenyl)methanesulfonamide (6a). Crystallization from methanol; yellow powder, $71 \%$ yield; mp 109-110 ${ }^{\circ}$; IR $\left(\nu, \mathrm{cm}^{-1}\right)$ : 3039, 2983, 1613, 1030. ${ }^{1} \mathrm{H}-\mathrm{NMR}$ $\left(400 \mathrm{MHz}_{\mathrm{CDCl}}\right): 11.34(1 \mathrm{H}, \mathrm{s}, \mathrm{NH}), 7.22(2 \mathrm{H}, \mathrm{d}, J=8.4 \mathrm{~Hz}$, Ar-H), $6.97(2 \mathrm{H}, \mathrm{d}, J=8.4 \mathrm{~Hz}, \mathrm{Ar}-\mathrm{H}), 4.96\left(2 \mathrm{H}, \mathrm{s}, \mathrm{C}_{5} \mathrm{H}_{4}\right)$, $4.39\left(2 \mathrm{H}, \mathrm{s}, \mathrm{C}_{5} \mathrm{H}_{4}\right), 4.04\left(5 \mathrm{H}, \mathrm{s}, \mathrm{C}_{5} \mathrm{H}_{5}\right), 3.22\left(3 \mathrm{H}, \mathrm{s}, \mathrm{CH}_{3}\right)$. ${ }^{13} \mathrm{C}-\mathrm{NMR}\left(100 \mathrm{MHz}, \mathrm{CDCl}_{3}\right): 34.6,67.2,70.1,70.4,84.3,114.3$, 127.1, 129.6, 138.4. Elemental analysis for $\mathrm{C}_{17} \mathrm{H}_{17} \mathrm{FeNO}_{2} \mathrm{~S}$ : Calculated: C, 57.48; H, 4.82; N, 3.94; S, 9.03\%. Found: C, 57.41; H, 4.89; N, 3.85; S, 9.11\%.

2.3.2. N-(4-Ferrocenylphenyl)ethanesulfonamide (6b). Crystallization from methanol; yellow powder, $74 \%$ yield; mp 132-133 ${ }^{\circ} \mathrm{C}$; IR $\left(\nu, \mathrm{cm}^{-1}\right): 3056,2989,1619,1023 .{ }^{1} \mathrm{H}-\mathrm{NMR}$ $\left(400 \mathrm{MHz} \mathrm{CDCl}_{3}\right): 11.23(1 \mathrm{H}, \mathrm{s}, \mathrm{NH}), 7.45(2 \mathrm{H}, \mathrm{d}, J=8.4 \mathrm{~Hz}$,
Ar- $\mathrm{H}), 6.81(2 \mathrm{H}, \mathrm{d}, J=8.4 \mathrm{~Hz}, \mathrm{Ar}-\mathrm{H}), 5.01\left(2 \mathrm{H}, \mathrm{s}, \mathrm{C}_{5} \mathrm{H}_{4}\right)$, $4.42\left(2 \mathrm{H}, \mathrm{s}, \mathrm{C}_{5} \mathrm{H}_{4}\right), 4.01\left(5 \mathrm{H}, \mathrm{s}, \mathrm{C}_{5} \mathrm{H}_{5}\right), 3.40(2 \mathrm{H}, \mathrm{q}, J=7.6 \mathrm{~Hz}$, $\left.\mathrm{CH}_{2}\right), 1.52\left(3 \mathrm{H}, \mathrm{t}, J=7.6 \mathrm{~Hz}, \mathrm{CH}_{3}\right) .{ }^{13} \mathrm{C}-\mathrm{NMR}(100 \mathrm{MHz}$, $\mathrm{CDCl}_{3}$ ): 23.1, 48.3, 67.6, 70.2, 70.5, 84.5, 119.7, 128.5, 133.9, 137.5 . Elemental analysis for $\mathrm{C}_{18} \mathrm{H}_{19} \mathrm{FeNO}_{2} \mathrm{~S}$ : Calculated: $\mathrm{C}, 58.55$; H, 5.19; N, 3.79; S, 8.68\%. Found: C, 58.69; H, 5.16; N, 3.71; S, $8.56 \%$.

2.3.3. N-(4-Ferrocenylphenyl)benzenesulfonamide (6c). Crystallization from ethanol; orange powder, 68\% yield; mp 174$175^{\circ} \mathrm{C}$; IR $\left(\nu, \mathrm{cm}^{-1}\right): 3087,1612,1015 .{ }^{1} \mathrm{H}-\mathrm{NMR}(400 \mathrm{MHz}$, $\left.\mathrm{CDCl}_{3}\right): 11.31(1 \mathrm{H}, \mathrm{s}, \mathrm{NH}), 7.25-7.61(7 \mathrm{H}, \mathrm{m}, \mathrm{Ar}-\mathrm{H}), 6.96(2 \mathrm{H}$, $\mathrm{d}, J=8.6 \mathrm{~Hz}, \mathrm{Ar}-\mathrm{H}), 4.94\left(2 \mathrm{H}, \mathrm{s}, \mathrm{C}_{5} \mathrm{H}_{4}\right), 4.40\left(2 \mathrm{H}, \mathrm{s}, \mathrm{C}_{5} \mathrm{H}_{4}\right)$, $4.03\left(5 \mathrm{H}, \mathrm{s}, \mathrm{C}_{5} \mathrm{H}_{5}\right) .{ }^{13} \mathrm{C}-\mathrm{NMR}\left(100 \mathrm{MHz}, \mathrm{CDCl}_{3}\right)$ : 67.4, 70.1, 70.4, 84.2, 119.3, 125.1, 127.4, 121.1, 133.4, 134.2, 140.9. Elemental analysis for $\mathrm{C}_{22} \mathrm{H}_{19} \mathrm{FeNO}_{2} \mathrm{~S}$ : Calculated: C, 63.32; $\mathrm{H}, 4.59 ; \mathrm{N}$, 3.36; S, 7.68\%. Found: C, 63.24; H, 4.52; N, 3.69; S, 7.75\%.

2.3.4. N-(4-Ferrocenylphenyl)-4-methylbenzensulfonamide (6d). Crystallization from ethanol; yellow powder, $68 \%$ yield; mp 169-170 $\mathrm{C}$; IR $\left(\nu, \mathrm{cm}^{-1}\right)$ : 3045, 2986, 1621, 1017. ${ }^{1} \mathrm{H}-\mathrm{NMR}\left(400 \mathrm{MHz}, \mathrm{CDCl}_{3}\right): 11.27(1 \mathrm{H}, \mathrm{s}, \mathrm{NH}), 7.81(2 \mathrm{H}, \mathrm{d}$, $J=8.2 \mathrm{~Hz}, \mathrm{Ar}-\mathrm{H}), 7.52(2 \mathrm{H}, \mathrm{d}, J=8.5 \mathrm{~Hz}, \mathrm{Ar}-\mathrm{H}), 7.28(2 \mathrm{H}$, $\mathrm{d}, J=8.2 \mathrm{~Hz}, \mathrm{Ar}-\mathrm{H}), 7.01(2 \mathrm{H}, \mathrm{d}, J=8.5 \mathrm{~Hz}, \mathrm{Ar}-\mathrm{H}), 4.70$ $\left(2 \mathrm{H}, \mathrm{s}, \mathrm{C}_{5} \mathrm{H}_{4}\right), 4.41\left(2 \mathrm{H}, \mathrm{s}, \mathrm{C}_{5} \mathrm{H}_{4}\right), 4.02\left(5 \mathrm{H}, \mathrm{s}, \mathrm{C}_{5} \mathrm{H}_{5}\right), 2.26$ $\left(3 \mathrm{H}, \mathrm{CH}_{3}\right) .{ }^{13} \mathrm{C}-\mathrm{NMR}\left(100 \mathrm{MHz}, \mathrm{CDCl}_{3}\right): 24.3,67.2,69.4$, 70.3, 84.4, 117.7, 122.6, 126.5, 128.2, 137.3, 137.4, 138.8, 140.4. Elemental analysis for $\mathrm{C}_{23} \mathrm{H}_{21} \mathrm{FeNO}_{2} \mathrm{~S}$ : Calculated: C, 64.05; H, 4.91; N, 3.25; S, 7.43\%. Found: C, 64.14; H, 4.82; N, 3.19; S, $7.32 \%$.

\section{Antimicrobial Evaluation}

Chemical compounds were individually tested against a panel of Gram-positive and Gram-negative bacterial pathogens, yeast, and fungi. Antimicrobial tests were carried out by the agar well diffusion method [33] using $100 \mu \mathrm{L}$ of suspension containing $1 \times 10^{6} \mathrm{CFU} / \mathrm{mL}$ of pathological tested bacteria and $1 \times 10^{6} / \mathrm{mL}$ of yeast spread on nutrient agar (NA) and Sabouraud dextrose agar (SDA), respectively. After the media had cooled and solidified, wells (10 $\mathrm{mm}$ in diameter) were made in the solidified agar and loaded with $100 \mu \mathrm{L}$ of tested compound solution prepared by dissolving $100 \mathrm{mg}$ of the chemical compound in one $\mathrm{mL}$ of dimethyl sulfoxide (DMSO). The inculcated plates were then incubated for $24 \mathrm{~h}$ at $37^{\circ} \mathrm{C}$ for bacteria and $48 \mathrm{~h}$ at $28^{\circ} \mathrm{C}$ for fungi. Negative controls were prepared using DMSO employed for dissolving the tested compound. Ciprofloxacin $(50 \mu \mathrm{g} / \mathrm{mL})$ and Ketoconazole $(50 \mu \mathrm{g} / \mathrm{mL})$ were used as standard for antibacterial and antifungal activities respectively. After incubation time, antimicrobial activity was evaluated by measuring the zone of inhibition against the test organisms and compared with that of the standard. Antimicrobial activities were expressed as inhibition diameter zones in millimeters ( $\mathrm{mm})$. The experiment was carried out in triplicate, and the average zone of inhibition was calculated. Compounds that showed significant growth inhibition zones $(>14 \mathrm{~mm})$ using the twofold 
serial dilution technique were further evaluated for their minimal inhibitory concentrations (MIC).

3.1. Minimal Inhibitory Concentration (MIC) Measurement. The microdilution susceptibility test in Müeller Hinton Broth (Oxoid) was used for the determination of antibacterial activity, and Sabouraud Liquid Medium (Oxoid) was used for the determination of antifungal activity. Stock solutions of the tested compounds, Ciprofloxacin, and Ketoconazole were prepared in DMF at concentration of $1000 \mathrm{mg} / \mathrm{mL}$. Twofold serial dilutions of the tested compounds solutions were prepared using the proper nutrient broth. The final concentration of the solutions was $132,66,33,16.5$, and $8.25 \mu \mathrm{g} / \mathrm{mL}$. The tubes were then inoculated with the test organisms, grown in their suitable broth at $37^{\circ} \mathrm{C}$ for $24 \mathrm{~h}$ for bacteria (about $1 \times 10^{6} \mathrm{CFU} / \mathrm{mL}$ ). each $5 \mathrm{~mL}$ received $0.1 \mathrm{~mL}$ of the previous inoculum and incubated at $37^{\circ} \mathrm{C}$ for $24 \mathrm{~h}$. The lowest concentration showing no growth was taken as the minimum inhibitory concentration (MIC). Control experiments with DMF and uninoculated media were run parallel to the test compounds under the same conditions. The MIC $(\mathrm{mg} / \mathrm{mL})$ and inhibition zone diameters values are recorded in Table 1.

\section{Results and Discussion}

4.1. Chemistry. The synthetic strategies adopted for the synthesis of the intermediates and target compounds are depicted in Scheme 1. The starting material compound 2 (4nitrophenylferrocene) was synthesized through arylation of ferrocene by a diazonium salt under phase transfer conditions, according to the literature [31]. The reduction of compound $\mathbf{2}$ with tin in acidic condition gives compound $\mathbf{3}$ (4-ferrocenylaniline) [32].

The urea $(\mathbf{4 a}-\mathbf{4 e})$ and thiourea derivatives $(\mathbf{4} \mathbf{f}-\mathbf{4 j})$ were obtained by the reaction of 4 -ferrocenylaniline with the appropriate isocyanates and isothiocyanates, respectively, in ethanol. The sulfonamide derivatives $(\mathbf{5} \mathbf{a}-\mathbf{5} \mathbf{d})$ were synthesized by the reaction of 4 -ferrocenylaniline with the appropriate sulfonic acid in the presence of dicyclohexylcarbodiimide/dimethylaminopyridine (DCC/DMAP).

The chemical structures of the title compounds were elucidated by ${ }^{1} \mathrm{H}-\mathrm{NMR},{ }^{13} \mathrm{C}-\mathrm{NMR}$, and FT-IR spectra and elemental analysis. Elemental analysis data of all products were in good agreement with the calculated values. IR spectra of all compounds showed all characteristic peaks. The absence of $\mathrm{N}-\mathrm{H}$ at $3500-3300 \mathrm{~cm}^{-1}$ confirmed the formation of urea, thiourea, and sulfonamide. ${ }^{1} \mathrm{H}-\mathrm{NMR}$ and ${ }^{13} \mathrm{C}$-NMR spectra of the synthesized compounds were recorded in $\mathrm{CDCl}_{3}$ relative to TMS as reference. The ${ }^{1} \mathrm{H}$ NMR spectrum showed signals in the region at $6.69-7.73 \mathrm{ppm}$ corresponding to the aromatic phenyl protons. The benzene ring directly attached to ferrocene contained two types of protons which appeared as a doublet with coupling constant of $8.4-8.6 \mathrm{~Hz}$. Substituted cyclopentadiene contained two types of protons, which appeared as two singlets at 4.394.48 and $4.93-5.04 \mathrm{ppm}$, respectively. All five protons of unsubstituted cyclopentadiene were chemically equivalent and appeared in ${ }^{1} \mathrm{H}$-NMR spectra as singlets at 4.00 $4.04 \mathrm{ppm}$. In the ${ }^{1} \mathrm{H}-\mathrm{NMR}$ spectra, the $\mathrm{N}-\mathrm{H}$ protons of the urea $(\mathbf{4 a}-\mathbf{4 e})$ and thiourea $(\mathbf{5} \mathbf{a}-\mathbf{5 e})$ derivatives were observed as two separate singlets at $9.43-9.94$ and $10.73-11.03 \mathrm{ppm}$, respectively. The $\mathrm{N}-\mathrm{H}$ protons of the sulfonamide derivatives (6a-6d) were observed as singlet at 11.27-11.34. In the ${ }^{13} \mathrm{C}$ NMR spectra, the compounds $4 \mathbf{a}-\mathbf{4 e}$ showed a signal at $155.0-156.1 \mathrm{ppm}$ due to $(\mathrm{C}=\mathrm{O})$ of urea derivatives. Thiourea derivatives $\mathbf{5 a}-\mathbf{5 e}$ showed a signal at 179.2-180.5 ppm due to $(\mathrm{C}=\mathrm{S})$.

4.2. Antimicrobial Activity. Fourteen of the newly synthesized target compounds were evaluated for their in vitro antibacterial activities at $100 \mu \mathrm{g} / \mathrm{mL}$ concentration against Staphylococcus aureus ATCC 29213 and Bacillus subtilis ATCC 6633 as examples of Gram-positive bacteria and Klebsiella pneumonia ATCC13883 and Escherichia coli ATCC 25922 as examples of Gram-negative bacteria. They were also evaluated for their in vitro antifungal potential against Saccharomyces cerevisiae and Candida albicans NRRL Y477 fungal strains. Agar-diffusion method was used for the determination of the preliminary antibacterial and antifungal activities. Ciprofloxacin and Ketoconazole were used as reference drugs. The results were recorded for each tested compound as the average diameter of inhibition zones (IZ) of bacterial or fungal growth around the disks in $\mathrm{mm}$. The results depicted in Table 1 revealed that most of tested compounds displayed variable inhibitory effects on the growth of the tested Gram-positive and Gram-negative bacterial strains and also against antifungal strains.

In general, most of the urea derivatives revealed better activity against the Gram-positive rather than the Gramnegative bacteria. Most of sulfonamide derivatives have superior significant antifungal potency than antibacterial potency. It would be also noticed that compounds belonging to the urea and thiourea groups exhibited better antibacterial potentials than members of the sulfonamide groups. Compounds $\mathbf{4 b}, \mathbf{4 c}, \mathbf{5 b}$, and $\mathbf{6 b}$ exhibited the highest potency against tested organisms with respect to reference drugs. Compound $\mathbf{4 b}$ inhibited the growth of $S$. aureus ATCC 29213, B. subtilis ATCC6633, and K. pneumonia ATCC13883 with inhibition zones 33,31 , and $32 \mathrm{~mm}$, respectively. While compounds $\mathbf{5 b}$ and $\mathbf{5 e}$ showed excellent activity against $K$. pneumonia ATCC13883 and E. coli ATCC 25922 of Gramnegative bacteria, also compounds $\mathbf{6 b}$ and $\mathbf{6} \mathbf{d}$ showed highest activity against S. cerevisiae and C. albicans NRRL Y-477 fungal strains.

The minimum inhibitory concentration (MIC) of the synthesized compounds against highly inhibited organisms is reported in Table 2. Compound $\mathbf{4 b}$ exhibited low MIC $(8.25 \mu \mathrm{g} / \mathrm{mL})$ against S. aureus ATCC 29213, B. subtilis ATCC 6633, and K. pneumonia ATCC13883. On the other hand, compound $4 \mathbf{b}$ revealed high MIC $(132 \mu \mathrm{g} / \mathrm{mL})$ against $C$. albicans NRRL Y-477 fungal strains. Compounds $\mathbf{5 b}$ and $\mathbf{5 e}$ showed MIC $8.25 \mu \mathrm{g} / \mathrm{mL}$ against K. pneumonia ATCC13883 and E. coli ATCC 25922 of Gram-negative bacteria. Additionally, compounds 5d, 6b, and $\mathbf{6 d}$ exhibited MIC $8.25 \mu \mathrm{g} / \mathrm{mL}$ against $S$. cerevisiae, and also $\mathbf{6 a}$ and $\mathbf{6 d}$ showed MIC $8.25 \mu \mathrm{g} / \mathrm{mL}$ against $C$. albicans NRRL Y-477 fungal strains. 
TABLE 1: Antimicrobial activity expressed as inhibition diameter zones in millimeters ( $\mathrm{mm}$ ) of chemical compounds against the pathological strains based on well diffusion assay.

\begin{tabular}{|c|c|c|c|c|c|c|}
\hline \multirow{4}{*}{ Compound } & \multicolumn{6}{|c|}{ Zone of inhibition (mm) } \\
\hline & \multicolumn{4}{|c|}{ Bacteria } & \multicolumn{2}{|c|}{ Fungi } \\
\hline & \multicolumn{2}{|c|}{ Gram-positive } & \multicolumn{2}{|c|}{ Gram-negative } & \multirow{2}{*}{ S. cerevisiae } & \multirow{2}{*}{ C. albicans } \\
\hline & S. aureus & B. subtilis & K. pneumoniae & E. coli & & \\
\hline $4 a$ & 22 & 18 & 18 & 14 & 19 & 16 \\
\hline $4 b$ & 33 & 31 & 32 & 27 & 16 & 15 \\
\hline $4 c$ & 30 & 32 & 27 & 32 & 20 & 21 \\
\hline $4 d$ & 20 & 19 & 24 & 27 & 18 & 16 \\
\hline $4 e$ & 23 & 18 & 18 & 19 & 14 & 19 \\
\hline $5 \mathbf{a}$ & 28 & 26 & 24 & 24 & 26 & 29 \\
\hline $5 \mathbf{b}$ & 25 & 27 & 30 & 31 & 24 & 28 \\
\hline $5 c$ & 24 & 28 & 28 & 24 & 21 & 32 \\
\hline $5 d$ & 23 & 30 & 26 & 28 & 29 & 26 \\
\hline $5 e$ & 26 & 22 & 32 & 33 & 24 & 26 \\
\hline $6 a$ & 24 & 28 & 24 & 25 & 26 & 30 \\
\hline $6 b$ & 22 & 25 & 29 & 28 & 32 & 34 \\
\hline $6 c$ & 28 & 24 & 17 & 22 & 24 & 18 \\
\hline $6 d$ & 22 & 23 & 26 & 28 & 30 & 30 \\
\hline Ciprofloxacin & 30 & 30 & 29 & 24 & NT & NT \\
\hline Ketoconazole & NT & NT & NT & NT & 30 & 31 \\
\hline
\end{tabular}

The experiment was carried out in triplicate, and the average zone of inhibition was calculated.

NT: not tested.

TABLE 2: Minimum inhibitory concentration $(\mu \mathrm{g} / \mathrm{mL})$ against the pathological strains based on twofold serial dilution technique.

\begin{tabular}{|c|c|c|c|c|c|c|}
\hline \multirow{4}{*}{ Compound } & \multicolumn{6}{|c|}{ MIC in $\mu \mathrm{g} / \mathrm{mL}$} \\
\hline & \multicolumn{4}{|c|}{ Bacteria } & \multicolumn{2}{|c|}{ Fungi } \\
\hline & \multicolumn{2}{|c|}{ Gram-positive } & \multicolumn{2}{|c|}{ Gram-negative } & \multirow{2}{*}{ S. cerevisiae } & \multirow{2}{*}{ C. albicans } \\
\hline & S. aureus & B. subtilis & K. pneumoniae & E. coli & & \\
\hline $4 a$ & 33 & 66 & 66 & 132 & 66 & 132 \\
\hline $4 b$ & 8.25 & 8.25 & 8.25 & 16.5 & 132 & 132 \\
\hline $4 c$ & 16.5 & 8.25 & 16.5 & 8.25 & 66 & 66 \\
\hline $4 d$ & 66 & 33 & 16.5 & 16.5 & 66 & 132 \\
\hline $4 e$ & 33 & 66 & 66 & 66 & 132 & 66 \\
\hline $5 a$ & 16.5 & 16.5 & 16.5 & 33 & 16.5 & 8.25 \\
\hline $5 b$ & 33 & 16.5 & 8.25 & 8.25 & 33 & 16.5 \\
\hline $5 c$ & 33 & 16.5 & 16.5 & 33 & 16.5 & 8.25 \\
\hline $5 d$ & 33 & 8.25 & 33 & 16.5 & 8.25 & 33 \\
\hline $5 e$ & 16.5 & 33 & 8.25 & 8.25 & 33 & 33 \\
\hline $6 a$ & 33 & 16.5 & 33 & 33 & 16.5 & 8.25 \\
\hline $6 b$ & 33 & 33 & 16.5 & 16.5 & 8.25 & 16.5 \\
\hline $6 c$ & 16.5 & 33 & 66 & 33 & 33 & 66 \\
\hline $6 d$ & 33 & 66 & 33 & 16.5 & 8.25 & 8.25 \\
\hline Ciprofloxacin & 8.25 & 8.25 & 8.25 & 16.5 & NT & NT \\
\hline Ketoconazole & NT & NT & NT & NT & 8.25 & 8.25 \\
\hline
\end{tabular}

NT: not tested.

\section{Conclusion}

In conclusion, the objective of the present study was to synthesize and investigate the antimicrobial activities of some novel ferrocene derivatives carrying urea, thiourea, and sulfonamide groups with the hope of discovering new structure leads serving as potent antimicrobial agents. Amongst the tested compounds, $\mathbf{4 b}, \mathbf{4} \mathbf{c}, \mathbf{5} \mathbf{b}$, and $\mathbf{6 b}$ displayed excellent 


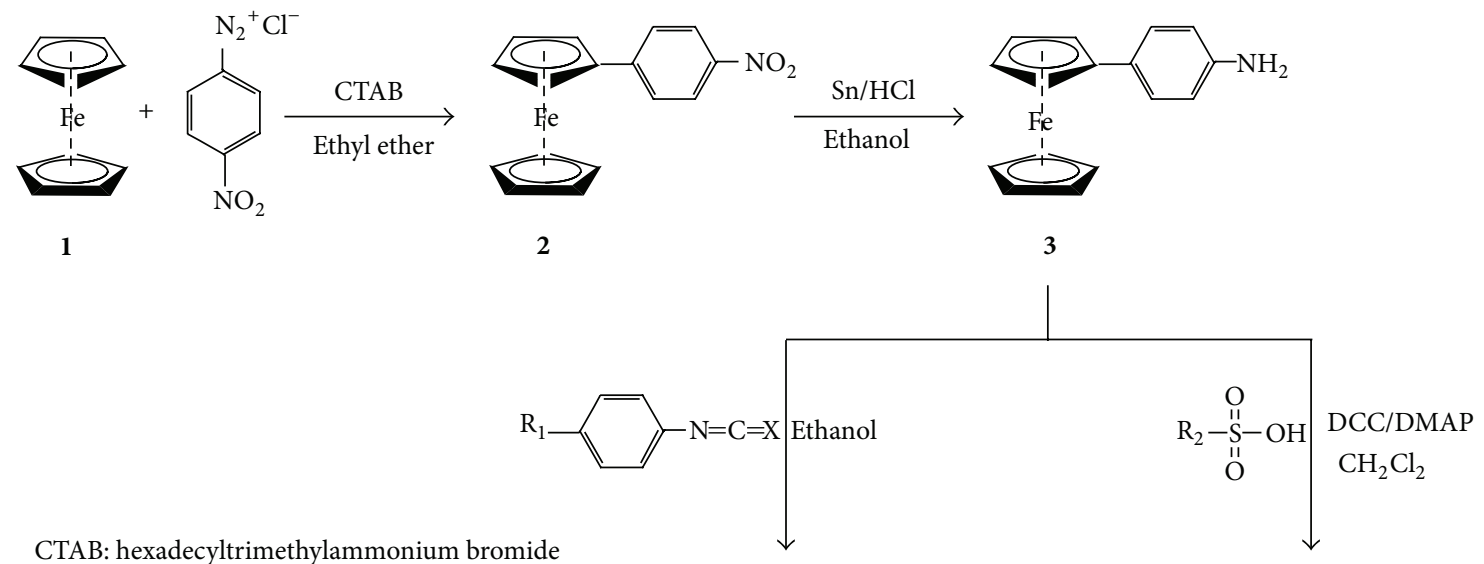

DCC: dicyclohexylcarbodiimide

DMAP: 4- $N, N^{\prime}$-dimethylaminopyridine

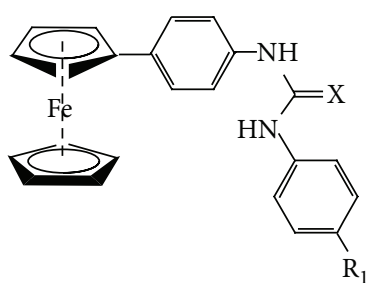

$4 a-4 e, 5 a-5 e$

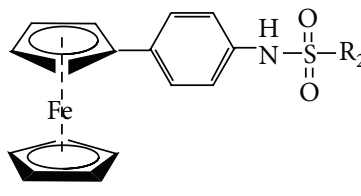

$6 a-6 d$

\begin{tabular}{l|ll|l|ll} 
& $\mathrm{X}$ & $\mathrm{R}_{1}$ & & $\mathrm{X}$ & $\mathrm{R}_{1}$ \\
\hline $\mathbf{4 a}$ & $\mathrm{O}$ & $-\mathrm{H}$ & $\mathbf{5 a}$ & $\mathrm{S}$ & $-\mathrm{H}$ \\
$\mathbf{4 b}$ & $\mathrm{O}$ & $-\mathrm{Cl}$ & $\mathbf{5 b}$ & $\mathrm{S}$ & $-\mathrm{Cl}$ \\
$\mathbf{4 c}$ & $\mathrm{O}$ & $-\mathrm{Br}$ & $\mathbf{5 c}$ & $\mathrm{S}$ & $-\mathrm{Br}$ \\
$\mathbf{4 d}$ & $\mathrm{O}$ & $-\mathrm{CH}_{3}$ & $\mathbf{5 d}$ & $\mathrm{S}$ & $-\mathrm{CH}_{3}$ \\
$\mathbf{4 e}$ & $\mathrm{O}$ & $-\mathrm{OCH}_{3}$ & $\mathbf{5 e}$ & $\mathrm{S}$ & $-\mathrm{OCH}_{3}$
\end{tabular}

\begin{tabular}{l|l} 
& $\mathrm{R}_{2}$ \\
\hline $\mathbf{6 a}$ & $-\mathrm{CH}_{3}$ \\
$\mathbf{6 b}$ & - \\
$\mathbf{6 c}$
\end{tabular}

SCHEME 1: Synthesis of ferrocene derivatives carrying urea, thiourea and sulfonamide moieties.

antimicrobial activity. These preliminary results are beneficial for further studies in developing new urea, thiourea, and sulfamide substituted ferrocene derivatives as potential antimicrobial agents.

\section{Acknowledgment}

This study was supported by Gazi University BAP (Project no. 05/2012-36).

\section{References}

[1] D. K. Aneja, P. Lohan, S. Arora, C. Sharma, K. R. Aneja, and O. Prakash, "Synthesis of new pyrazolyl-2, 4-thiazolidinediones as antibacterial and antifungal agents," Organic Medicinal Chemistry Letter, vol. 1, no. 15, pp. 1-12, 2011.

[2] I. Berber, C. Cokmus, and E. Atalan, "Characterization of Staphylococcus species by SDS-PAGE of whole-cell and extracellular proteins," Microbiology, vol. 72, no. 1, pp. 42-47, 2003.

[3] S. Y. Abbas, M. A. M. S. El-Sharief, W. M. Basyouni, I. M. I. Fakhr, and E. W. El-Gammal, "Thiourea derivatives incorporating a hippuric acid moiety: synthesis and evaluation of antibacterial and antifungal activities," European Journal of Medicinal Chemistry, vol. 64, pp. 111-120, 2013.

[4] D. Nieto, A. M. González-Vadillo, S. Bruña, C. J. Pastor, A. E. Kaifer, and I. Cuadrado, "Pt(II)-activated coupling of aminoethylferrocene with benzonitrile. A facile access route to a new redox-active bis(ferrocenyl-amidine) anion sensor," Chemical Communications, vol. 47, no. 37, pp. 10398-10400, 2011.

[5] C. P. Andrieux, C. Blocman, J. M. Dumas-Bouchiat, F. M'Halla, and J. M. Savéant, "Determination of the lifetimes of unstable ion radicals by homogeneous redox catalysis of electrochemical reactions. Application to the reduction of aromatic halides," Journal of the American Chemical Society, vol. 102, no. 11, pp. 3806-3813, 1980.

[6] M. Fuentealba, J.-R. Hamon, D. Carrillo, and C. Manzur, "Trinuclear $\pi$-conjugated chromophores formed by a neutral ferrocenyl group and a cationic mixed ruthenium sandwich linked through an unsymmetrical Schiff-base complex spacer," New Journal of Chemistry, vol. 31, no. 10, pp. 1815-1825, 2007.

[7] S. K. Pal, A. Krishnan, P. K. Das, and A. G. Samuelson, "Schiff base linked ferrocenyl complexes for second-order nonlinear optics," Journal of Organometallic Chemistry, vol. 604, no. 2, pp. 248-259, 2000. 
[8] P. Li, I. J. Scowen, J. E. Davies, and M. A. Halcrow, "Coordination chemistry of bis(ferrocenylcarbaldimine) Schiff bases," Journal of the Chemical Society, Dalton Transactions, no. 22, pp. 3791-3799, 1998.

[9] L. Mishra and S. K. Dubey, "Emission switching of ferrocenyl Schiff bases and a representative ruthenium complex in alkaline DMSO: absorption, electrochemical and microstructural studies," Spectrochimica Acta Part A, vol. 68, no. 2, pp. 364-368, 2007.

[10] A.-E. Navarro, N. Spinelli, C. Moustrou, C. Chaix, B. Mandrand, and H. Brisset, "Automated synthesis of new ferrocenylmodified oligonucleotides: study of their properties in solution," Nucleic Acids Research, vol. 32, no. 17, pp. 5310-5319, 2004.

[11] C. Biot, L. Delhaes, L. A. MacIejewski et al., "Synthetic ferrocenic mefloquine and quinine analogues as potential antimalarial agents," European Journal of Medicinal Chemistry, vol. 35, no. 7-8, pp. 707-714, 2000.

[12] H. Yu, L. Shao, and J. Fang, "Synthesis and biological activity research of novel ferrocenyl-containing thiazole imine derivatives," Journal of Organometallic Chemistry, vol. 692, no. 5, pp. 991-996, 2007.

[13] M. Zora and M. Görmen, "Synthesis of ferrocenyl pyrazoles by the reaction of (2-formyl-1-chlorovinyl)ferrocene with hydrazines," Journal of Organometallic Chemistry, vol. 692, no. 22, pp. 5026-5032, 2007.

[14] B. Fábián, V. Kudar, A. Csámpai, T. Z. Nagy, and P. Sohár, "Synthesis, IR-, NMR-, DFT and X-ray study of ferrocenyl heterocycles from thiosemicarbazones-part 21: study on ferrocenes," Journal of Organometallic Chemistry, vol. 692, no. 25, pp. 5621-5632, 2007.

[15] Y.-S. Xie, H.-L. Zhao, H. Su et al., "Synthesis, single-crystal characterization and preliminary biological evaluation of novel ferrocenyl pyrazolo[1,5-a]pyrazin-4(5H)-one derivatives," European Journal of Medicinal Chemistry, vol. 45, no. 1, pp. 210-218, 2010.

[16] T. J. Kealy and P. L. Pauson, "A new type of organo-iron compound," Nature, vol. 168, no. 4285, pp. 1039-1040, 1951.

[17] A. J. Corry, Á. Mooney, D. O’Sullivan, and P. T. M. Kenny, "Synthesis, characterization and in vitro anti-cancer activity of $\mathrm{N}$-(ferrocenyl)benzoyl tri- and tetrapeptide esters," Inorganica Chimica Acta, vol. 362, no. 9, pp. 2957-2961, 2009.

[18] J. Zhang and R. Liu, "Synthesis, characterization and antioxidant activity of ferrocenylhydrazones," Journal of the Chemical Society of Pakistan, vol. 33, no. 3, pp. 356-359, 2011.

[19] L. dos Santos, L. A. Lima, V. Cechinel-Filho, R. Corrêa, F. de Campos Buzzi, and R. J. Nunes, "Synthesis of new 1-phenyl-3-4[(2E)-3-phenylprop-2-enoyl]phenyl-thiourea and urea derivatives with anti-nociceptive activity," Bioorganic and Medicinal Chemistry, vol. 16, no. 18, pp. 8526-8534, 2008.

[20] B. K. Sharma, S. K. Sharma, P. Singh, and S. Sharma, "A quantitative structure-activity relationship study of novel, potent, orally active, selective VEGFR-2 and PDGFR $\alpha$ tyrosine kinase inhibitors: derivatives of $N$-Phenyl- $N^{\prime}$-4-(4-quinolyloxy phenylurea as antitumor agents," Journal of Enzyme Inhibition and Medicinal Chemistry, vol. 23, no. 2, pp. 168-173, 2008.

[21] T. K. Venkatachalam, C. Mao, and F. M. Uckun, "Effect of stereochemistry on the anti-HIV activity of chiral thiourea compounds," Bioorganic and Medicinal Chemistry, vol. 12, no. 15, pp. 4275-4284, 2004.

[22] M. Struga, J. Kossakowski, E. Kędzierska, S. Fidecka, and J. Stefańska, "Synthesis and pharmacological activity of urea and thiourea derivatives of 4-azatricyclo[5.2.2.02,6]undec-8-ene3,5-dione," Chemical and Pharmaceutical Bulletin, vol. 55, no. 5, pp. 796-799, 2007.

[23] A. K. Gadad, C. S. Mahajanshetti, S. Nimbalkar, and A. Raichurkar, "Synthesis and antibacterial activity of some 5guanylhydrazone/thiocyanato-6-arylimidazo[2,1-b]-1,3,4thiadiazole-2-sulfon amide derivatives," European Journal of Medicinal Chemistry, vol. 35, no. 9, pp. 853-857, 2000.

[24] F. Zani and P. Vicini, "Antimicrobial activity of some 1,2benzisothiazoles having a benzenesulfonamide moiety," Archiv der Pharmazie, vol. 331, no. 6, pp. 219-223, 1998.

[25] Z. Brzozowski, J. Sławiński, F. Saczewski, A. Innocenti, and C. T. Supuran, "Carbonic anhydrase inhibitors: synthesis and inhibition of the human cytosolic isozymes I and II and transmembrane isozymes IX, XII (cancer-associated) and XIV with 4-substituted 3-pyridinesulfonamides," European Journal of Medicinal Chemistry, vol. 45, no. 6, pp. 2396-2404, 2010.

[26] G. Renzi, A. Scozzafava, and C. T. Supuran, "Carbonic anhydrase inhibitors: topical sulfonamide antiglaucoma agents incorporating secondary amine moieties," Bioorganic and Medicinal Chemistry Letters, vol. 10, no. 7, pp. 673-676, 2000.

[27] F. Saczewski, A. Innocenti, J. Sławiński et al., "Carbonic anhydrase inhibitors: inhibition of human cytosolic isozymes I and II and tumor-associated isozymes IX and XII with S-substituted 4-chloro-2-mercapto-5-methyl-benzenesulfonamides," Bioorganic and Medicinal Chemistry, vol. 16, no. 7, pp. 39333940, 2008.

[28] V. Garaj, L. Puccetti, G. Fasolis et al., "Carbonic anhydrase inhibitors: novel sulfonamides incorporating 1,3,5-triazine moieties as inhibitors of the cytosolic and tumour-associated carbonic anhydrase isozymes I, II and IX," Bioorganic and Medicinal Chemistry Letters, vol. 15, no. 12, pp. 3102-3108, 2005.

[29] G. P. Suresha, R. Suhas, W. Kapfo, and D. Channe Gowda, "Urea/thiourea derivatives of quinazolinone-lysine conjugates: synthesis and structure-activity relationships of a new series of antimicrobials," European Journal of Medicinal Chemistry, vol. 46, no. 6, pp. 2530-2540, 2011.

[30] H. M. Faidallah, K. A. Khan, and A. M. Asiri, "Synthesis and biological evaluation of new 3,5-di(trifluoromethyl)-1,2,4triazolesulfonylurea and thiourea derivatives as antidiabetic and antimicrobial agents," Journal of Fluorine Chemistry, vol. 132, no. 11, pp. 870-877, 2011.

[31] P. Hu, K.-Q. Zhao, and H.-B. Xu, "4-Nitrophenylferrocene," Molecules, vol. 6, no. 12, p. M249, 2001.

[32] H. Ping, K.-Q. Zhao, and H.-B. Xu, “4-Ferrocenylaniline," Molecules, vol. 6, no. 12, p. M250, 2001.

[33] A. C. Scott, "Laboratory control of antimicrobial therapy," in Mackie and Mac-Cartney Practical Medical Microbiology, J. G. Collee, J. P. Duguid, A. G. Fraser, and B. P. Marmion, Eds., pp. 161-181, Churchill Livingstone, 13th edition, 1989. 

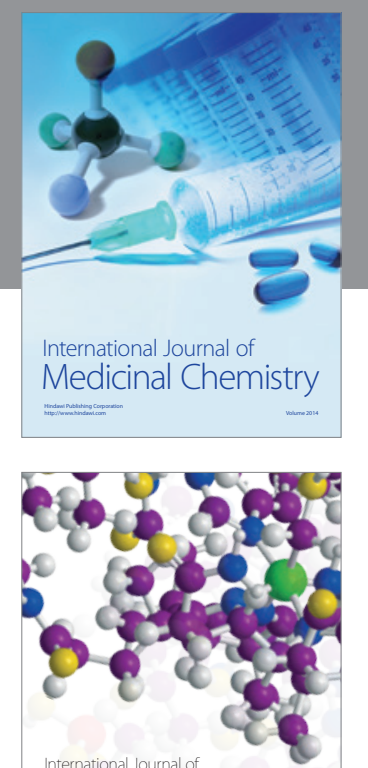

\section{Carbohydrate} Chemistry

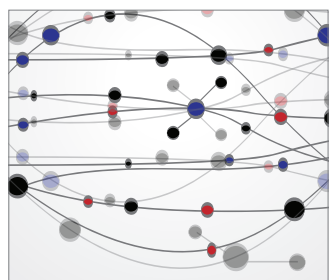

The Scientific World Journal
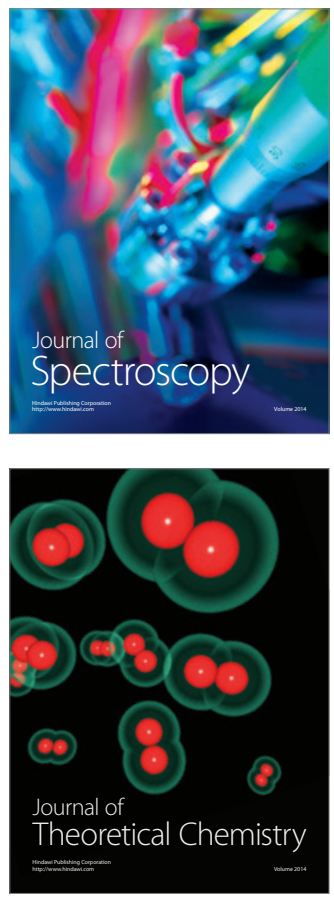
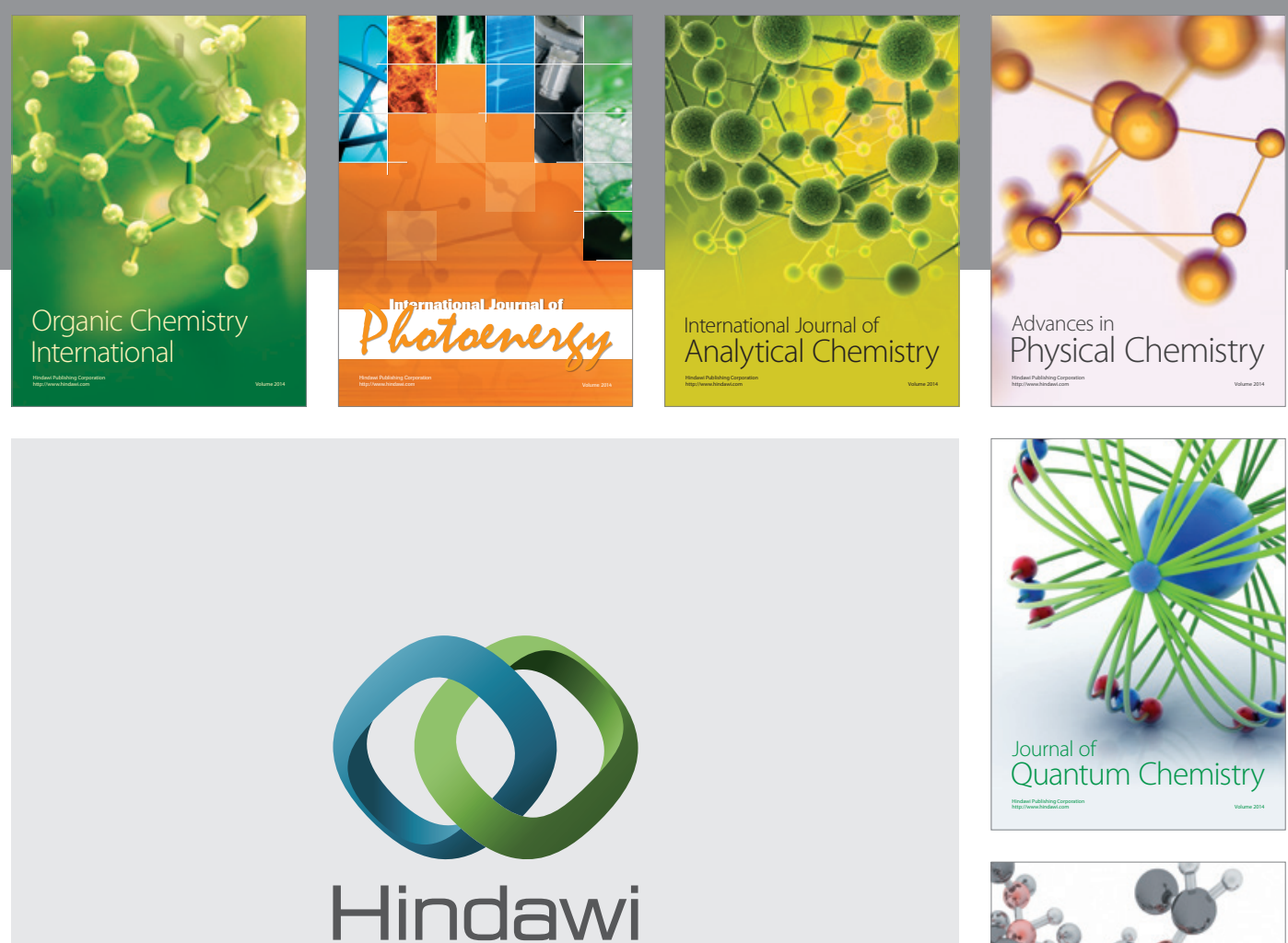

Submit your manuscripts at

http://www.hindawi.com

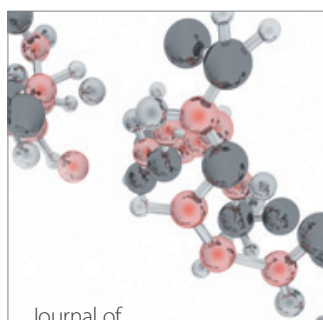

Analytical Methods

in Chemistry

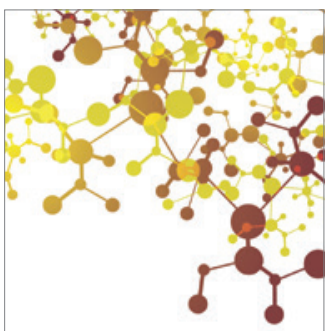

Journal of

Applied Chemistry

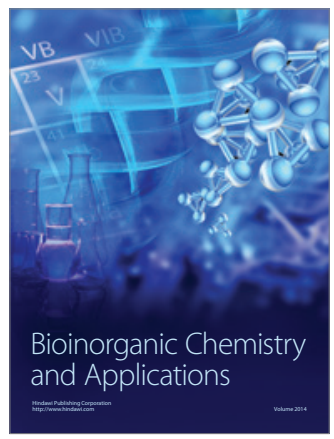

Inorganic Chemistry
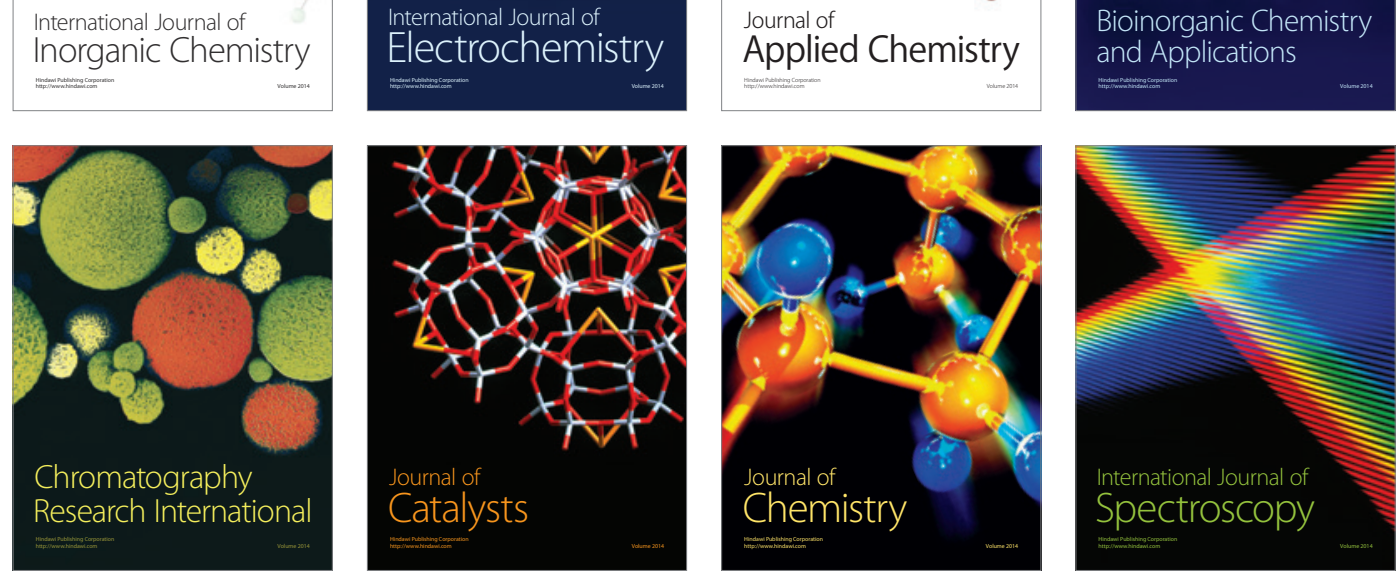